\begin{tabular}{|c|c|c|}
\hline $\begin{array}{c}\text { RESEARCH } \\
\text { ARTICLE }\end{array}$ & $\begin{array}{r}\text { ADVANCE RESEAR } \\
\text { Volume } 6 \text { | Issue }\end{array}$ & OCIAL SCIENCE \\
\hline $0=$ & DOI: 10.15740/HAS/ARJSS/6.1/77-81 & Visit us : www.researchjournal. \\
\hline
\end{tabular}

\title{
Emotional intelligence of adults working in government and non-government organizations
}

Rojina Tokpam*, Jinamoni Saikia and Tulika Borah Department of Human Development and Family Studies, College of Home Science, Assam Agricultural University, JORHAT (ASSAM) INDIA

(Email: mangaleima@gmail.com)

\section{ARTICLE INFO :}

$\begin{array}{lll}\text { Received } & : & 06.04 .2015 \\ \text { Revised } & : & 01.05 .2015 \\ \text { Accepted } & : & 17.05 .2015\end{array}$

KEY WORDS :

Emotional intelligence, Employed adults, Organizations

\section{HOW TO CITE THIS ARTICLE :}

Tokpam, Rojina, Saikia, Jinamoni and Borah, Tulika (2015). Emotional intelligence of adults working in government and non-government organizations. Adv. Res. J. Soc. Sci., 6 (1): 77-81.

*Author for correspondence

\begin{abstract}
The study was conducted to find out emotional intelligence levels of adults working in government and non-government organisations. A sample of 200 employed adults (27-40 years) of government and non-government organizations of Jorhat town of Assam were selected purposively for the study. For data collection, a standardized structured questionnaire named "Emotional Quotient Test" (EQ Test) was administered. Results revealed that majority of respondents of government as well as non-government organizations had high level of emotional intelligence. Significant difference was not found between the levels of emotional intelligence of the respondents working in government and non-government organizations.
\end{abstract}

